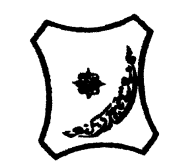

Bayero Journal of Pure and Applied Sciences, 10(1):162 - 165

ISSN 2006 - 6996

\title{
TITRIMETRIC DETERMINATION OF ARSENIC CONCENTRATION IN WATER SAMPLES COLLECTED FROM HADEJIA EMIRATE COUNCIL, JIGAWA STATE, NIGERIA
}

\author{
Aliyu S. M. \\ Department of Chemistry, Federal College of Education, Kano, Nigeria \\ baffasma@gmail.com; +234 7037729095
}

\begin{abstract}
This research is aimed at titrimetric determination of Arsenic concentration in samples collected from boreholes and irrigation channels of Hadejia Emirate council, Jigawa State, Nigeria. Twenty three samples were randomly collected using standard techniques. The $\mathrm{pH}$ of the samples was determined immediately at the collection site. The Arsenic concentration was determined using Flame Absorption Spectrophotometry (FAS). Results show the concentration of Arsenic from boreholes in the range of 0.006ppm to $0.014 \mathrm{ppm}$ with the mean of 0.011; while that of irrigation channels ranges from $0.006 \mathrm{ppm}$ to $0.010 \mathrm{ppm}$ with the mean of 0.009. This shows that all the samples from irrigation channels have Arsenic concentration below World Health Organization (WHO) as well as Standard Organization of Nigeria (SON) permissible limits. However, some samples from boreholes were a little bit above permissible limits of afore mention organizations. It is therefore recommended among others that government and private organizations should keep on monitoring this concentration at regular interval.
\end{abstract}

Keywords: Arsenic, Borehole, Irrigation Channels, FAS, WHO

\section{INTRODUCTION}

Arsenic is found widely in earths in oxidation states of $-3,0,+3$ and +5 , often as sulfides or metal arsenides or arsenates. In water, it is mostly present as arsenate $(+5)$, but in anaerobic conditions, it is likely to be present as arsenite $(+3)$. It is usually present in natural waters at concentrations of less than $1-2 \mu \mathrm{g} / \mathrm{l}$. However, in waters particularly ground waters, where there are sulfide mineral deposits and sedimentary deposits deriving from volcanic rocks, the concentrations can be significantly elevated (WHO, 2014).

Arsenic is found in the diet, particularly in fish and shellfish, in which it is found mainly in the less toxic organic form. There are only limited data on the preparation of inorganic arsenic in food, but these indicate that approximately $25 \%$ is present in the inorganic form, depending on the type of food. Apart from occupational exposure the most important routes of exposure are through food and drinking water. Where the concentration of arsenic in drinking water is $10 \mu \mathrm{g} / \mathrm{l}$ or greater, this will be dominant source of intake. In circumstances where soups or similar dishes are a staple part of the diet, the drinking water contribution through preparation of food will be even greater (WHO, 2011).
Numerous epidemiological studies have examined the risk of cancers associated with arsenic ingestion through drinking water. There is overwhelming evidence that consumption of elevated levels of arsenic through drinking water is casually related to the development of cancer at several sites. Nevertheless, there remain considerable uncertainty and controversy over both the mechanisms of carcinogenicity and the shape of the doseresponse curve at low intakes. The International Programmed on Chemical Safety (IPCS) concluded that long-term exposure to arsenic in drinking water is casually related to increased risks of cancer in the skin, lungs, bladder and kidney, as well as other skin changes, such as hyperkeratosis and pigmentation changes. The effects have been most thoroughly studied in Taiwan, China, but there is considerable evidence from studies on populations in other countries as well (WHO, 2011).

Arsenic has no known essential role in living organisms; exhibit extreme toxicity even at very low levels and exposure has been regarded as a threat to all forms of life especially human health (Eisler, 1985; Järup, 2003; Olmedo et al., 2013). However, some authors have suggested that arsenic perhaps might be an essential element for organisms at low concentrations (De Gieter et al., 2002). 
Special Conference Edition, November, 2017

Values greater than the provisional world health organization permissible level of $10 \mathrm{ppb}$ Arsenic in drinking water have been reported in surface waters in parts of Biu Volcanic Province, North-Eastern Nigeria with inhabitants of the area showing obvious symptoms of Arsenic poisoning (Usman and Lar, 2013). However, Arsenic value within WHO maximum permissible limit has been reported for the underground waters of Odede, Ogun State (Amori et al., 2013).

Therefore, this study was initiated and aimed at titrimetric determination of Arsenic concentration in water samples from boreholes and irrigation channels of Hadejia Emirate Council, Jigawa State, Nigeria, to ascertain whether the levels of Arsenic concentration in the water samples is sufficient to cause health hazards to living systems.

\section{MATERIALS AND METHODS}

Study Area

Hadejia emirate lies within longitude $9^{0} 58^{\prime} 4^{\prime \prime} \mathrm{E}$ to $10^{0} 60^{\prime} 9^{\prime \prime} \mathrm{E}$ and latitude $11^{0} 91^{l} 1^{\prime \prime} \mathrm{N}$ to $13^{0} 01^{\prime} 1^{\prime \prime} \mathrm{N}$ (Figure 1). The study area lies within Jigawa State, Nigeria, and consists of eight local governments. These include; Kaugama, Birniwa, Kiri Kasamma, Kafin Hausa, Auyo, Malam Madori, Guri and Hadejia (Figure 1). Observation shows that irrigation ferming is one of the major activities of people living in this area.

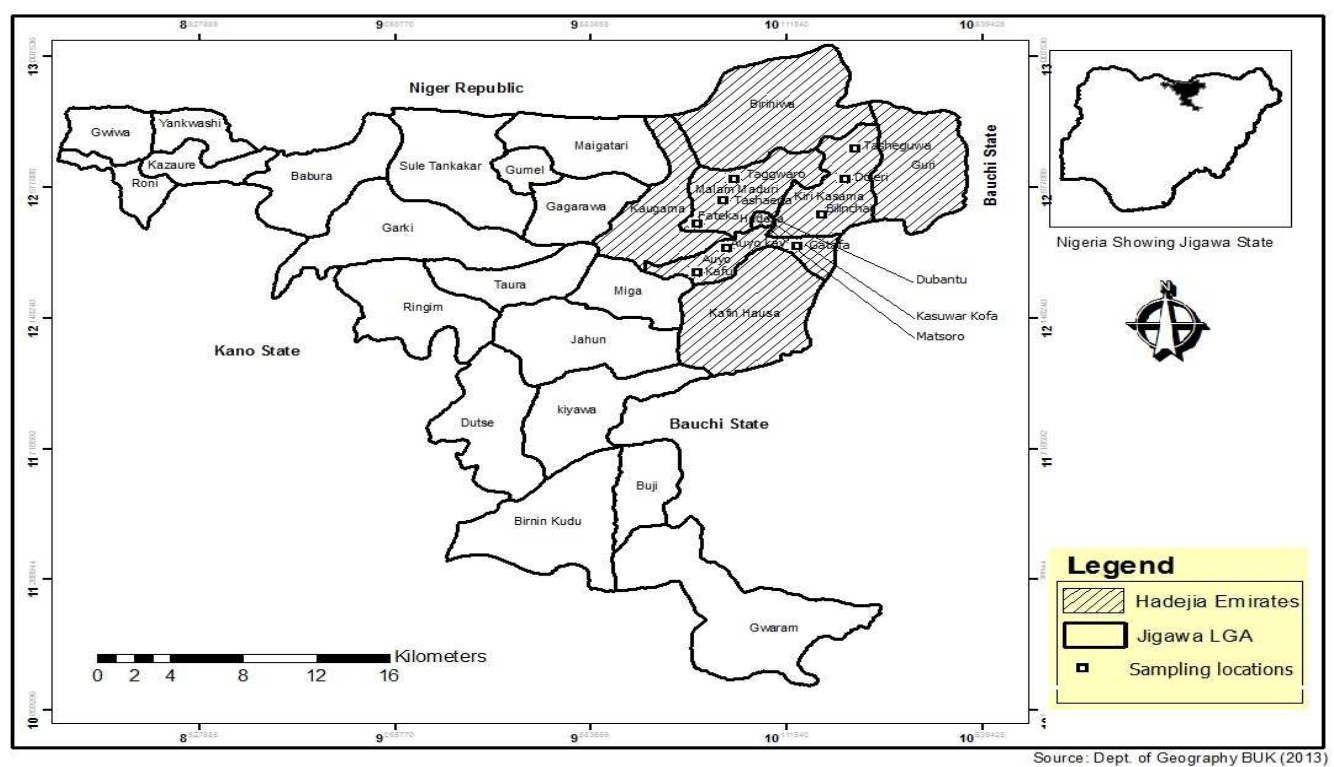

Figure 1: Map of Jigawa State showing the Hadejia Emirate Council and the Sampling sites.

\section{Sampling Technique}

Random sampling technique was used, in which the names of the eight local governments was folded in small papers. Four out of the eight local governments were randomly picked and selected. From the four selected local governments, three wards were selected as sampling locations (Figure 1). From each ward, two different water samples were collected. One from the borehole and the other from the irrigation channel except area that is not practicing irrigation like Gatafa ward in Malam Madori local government. A total of twentythree (23) samples were collected, twelve (12) from boreholes and eleven (11) from irrigation channels.

\section{Sample Pretreatment}

One liter (1L) double capped polyethene bottles were washed with $1 \mathrm{M} \mathrm{HNO}_{3}$, and then severally washed with distilled water. The polyethene bottles were then dried and labeled. At the collection site, few drops of concentrated nitric acid (Conc. $\mathrm{HNO}_{3}$ ) were added to each sample so as to prevent loss of metal, bacterial and fungal growth. The $\mathrm{pH}$ was measured at the sample collection site. Ice blocks were used to keep the samples at very low temperature before taken to the laboratory for analysis.

\section{Determination of Arsenic Concentration}

A standard titrimetric procedure that was previously validated by Garba et al. (2008) was employed. The procedure considers both organic and inorganic Arsenic to exist as initial $\mathrm{As}_{2} \mathrm{O}_{3}$ species that are equally available to the iodine molecules (Garba et al., 2008). 
$25 \mathrm{~cm}^{3}$ of each water sample was pipetted into a $250 \mathrm{~cm}^{3}$ conical flask and a spatula full of sodium bicarbonate was added followed by the addition of 3 to 4 drops of starch indicator. The resulting solution was titrated against $0.0001 \mathrm{M}$ iodine solution to the first appearance of deep blue color which marked the end point. The experiment was repeated 3 times within each sample.
Equations of the reaction:

$$
\mathrm{As}_{2} \mathrm{O}_{3}+2 \mathrm{H}_{2} \mathrm{O}+2 \mathrm{I}_{2} \rightarrow \mathrm{As}_{2} \mathrm{O}_{5}+4 \mathrm{H}^{+}+4 \mathrm{I}^{-}
$$

\section{RESULTS}

The results of $\mathrm{pH}$ of the samples were presented in Table 1. Where as that of Arsenic concentration was presented in Figure 2 .

TABLE 1: A Table Showing Sample Name, Sample Code and Sample pH.

\begin{tabular}{cllll}
\hline S/N & SAMPLE SITE & SAMPLE & \multicolumn{2}{c}{ pH } \\
& & CODE & BH & IRW \\
\hline 1. & Tasheguwa & Tas & 8.2 & 4.4 \\
2. & Doleri & Dol & 5.7 & 6.0 \\
3. & Bilinchai & Bil & 6.9 & 6.3 \\
4. & Dubantu & Dub & 6.3 & 4.3 \\
5. & Kasuwar Kofa & Kas & 9.3 & 4.3 \\
6. & Matsaro & Mat & 7.6 & 4.3 \\
7. & Kafur & Kaf & 5.1 & 4.7 \\
8. & Auyakayi & Auy & 5.8 & 4.5 \\
9. & Gatafa & Gat & 5.7 & 4.5 \\
10. & Tagwaro & Tag & 7.8 & 5.7 \\
11. & Tashena & Tsh & 4.5 & 4.9 \\
12. & Fateka & Fat & 9.6 & - \\
& WHO STANDARD & & 6.5 to 8.5 \\
\hline
\end{tabular}

\section{DISCUSSION}

The $\mathrm{pH}$ of borehole has the range of 4.5 to 9.6 with the lowest record in Tashena and highest in Fateka. For the irrigation channels, the range of $\mathrm{pH}$ is 4.3 to 6.3 (Table 1 ). The world health organization (WHO) standard for $\mathrm{pH}$ was in the range of 6.5 to 8.5. This shows that the boreholes have more $\mathrm{pH}$ value than the irrigation channel. $42 \%$ of the water samples from boreholes have $\mathrm{pH}$ value less than the WHO minimum value (6.5) i.e. less acidic. $17 \%$ of the samples were found to be above the world health organization maximum value (8.5) i.e. less basic. However, all the samples from irrigation channels were found to be below the world health organization minimum value of 6.5, that is less acidic. Never the less, Sa'eed and Mahmud (2014), reported TDS and pH to be within world health organization recommended range in a research conducted on water from boreholes of Fagge local government, Kano Metropolis. Except in sampling site at weather head Sabon Gari in which the $\mathrm{pH}$ level was found to be 6.2 which is slightly below the recommended value set by world health organization.

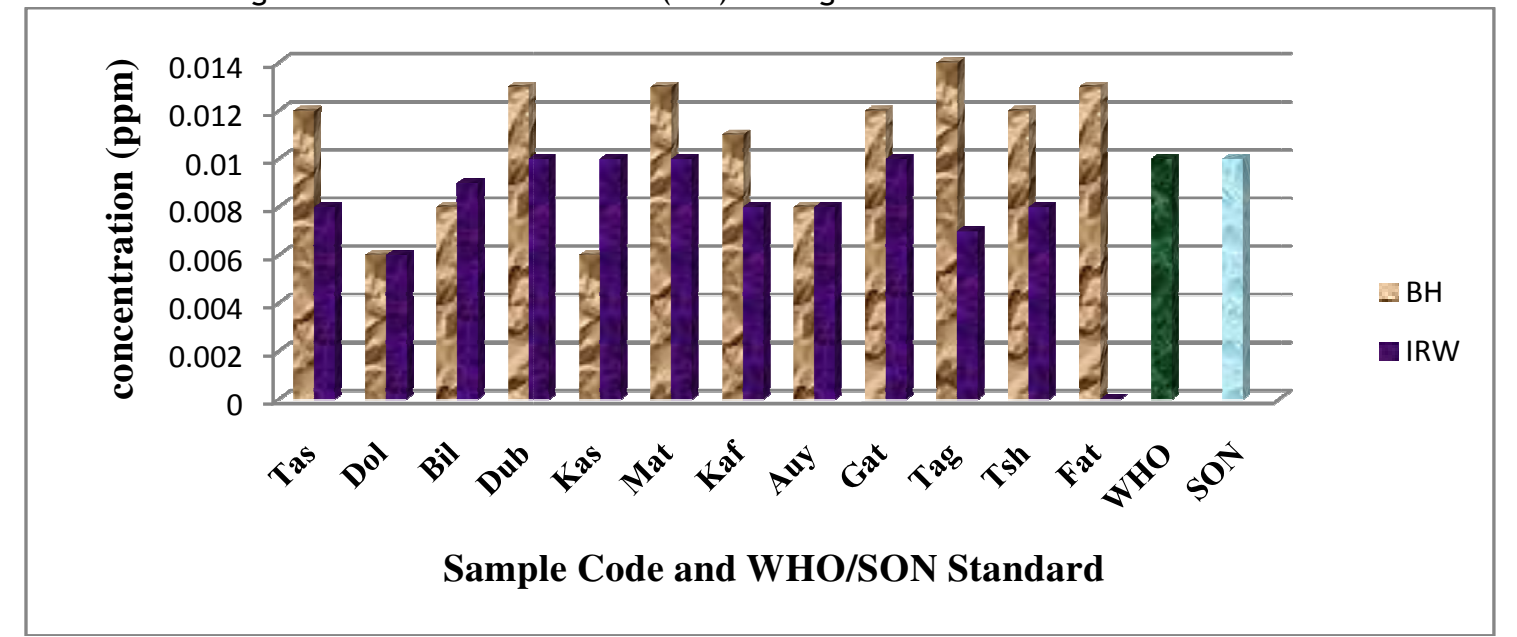

Figure 2: Frequency Distribution of Water Samples for Arsenic (ppm) With WHO and SON Standards. 
Special Conference Edition, November, 2017

The concentration of Arsenic in the borehole is from the range of $0.006 \mathrm{ppm}$ to $0.014 \mathrm{ppm}$ with the mean of 0.011 . While that of irrigation channel ranges from $0.006 \mathrm{ppm}$ to $0.010 \mathrm{ppm}$ with the mean of 0.009 . The world health organization permissible limit of Arsenic is $0.01 \mathrm{mgL}^{-1}$. The result showed that all the samples analyzed were found to be below the world health organization permissible limit in terms of Arsenic concentration (Fig. 2). This is in contrast with Garba et al., (2010), which reported high values of Arsenic above world health organization permissible limit in drinking water of Karaye local government, Kano State, Nigeria. In a similar case, Garba et al.(2008), reported high Arsenic concentration of $0.80 \mathrm{mg} / \mathrm{L}$ in Kutama and $0.765 \mathrm{mg} / \mathrm{L}$ in Getso, Gwarzo local government area, Kano State. They attributed these high concentrations to disposal of Arsenic containing materials, burning of solid wastes, natural processes, industrial activities and other human activities (Garba et al.,2008; Musa et al., 2008). Generally, low Arsenic species concentration are recorded in the samples perhaps because most of afore mentioned reasons are not seen in the study area. Values greater than the provisional world health organization permissible level of 10ppb Arsenic in drinking water (WHO, 2008) have been also reported in surface waters in parts of Biu Volcanic province, North Eastern Nigeria with inhabitants of the area showing obvious symptoms of Arsenic poisoning (Usman and Lar, 2013). Arsenic is used the production of pesticides, herbicides and insecticides. Arsenic is poisonous to almost all organic life. Arsenic

\section{REFERENCES}

Amori A.A., Oduntan O.O., Okeyode I.C., and Ojo S.O. (2013): Heavy Metal Concentration of Ground Deposits in Odeda Region, Ogun State, Nigeria. Journal of Environmental Research and Management. 4:5:253-259

De Gieter M., Leermakers M., Van Ryssen R., Noyen J., Geoyens I., and Baeyens W. (2002): Total and Toxic Arsenic Levels in North Sea Fish. Archives of Environmental Contamination and Toxicology. 46:406-417

Eisler R. (1988): Arsenic Hazards to fish, Wildlife and Invertebrates: a Synoptic Review. US Fish Wildlife Service Biological Report. 85:112:65

Garba Z.N., C.E. Gimba, Hamza S.A. and Galadima A. (2008): Titrimetric determination of Arsenic in well water from Getso and Kutama, Gwarzo L.G.A., Kano State, Nigeria. Chemistry Class Journal, 5:78-80

Järup L. (2003): Hazards of Heavy Metal Contamination. British Medical Bulletin. 68:167-182 contaminating groundwater is a natural occurrence around the world (http//www.h2odistributors.com, 2016).

\section{Conclusion}

The titrimetric determination of Arsenic was studied and the results of the $\mathrm{pH}$ for the water samples of boreholes were found to be within World Health Organization (WHO) and Standard Organization of Nigeria (SON) permissible limits except for Kasuwar Kofa and Fateka. This indicates that the water is good for drinking in terms of $\mathrm{pH}$. However, all the samples from irrigation have $\mathrm{pH}$ lower than World Health Organization and Standard Organization of Nigeria recommended values. Never the less, Arsenic concentration from irrigation samples were found to be below WHO/SON standards. Whilst, some samples from boreholes show concentration little above WHO/SON recommended values. Therefore, the water from the study area is good both for drinking and irrigation activities in terms of $\mathrm{pH}$ and Arsenic concentration.

\section{Recommendation}

The following recommendations have to be given urgent attention;

- There is need for government and private organizations to keep on monitoring this concentration at regular interval.

- Public campaign on the need to treat borehole water before drinking.

- Borehole should not be sited indiscriminately in the areas without making proper geological surveys and studies.

Musa H., Yakasai L.A, Musa K.Y., Isah A.B. and Mshelbwala K. (2008): J. AppL. Sci., 8:11:2183-2186

Olmedo P., Pla A., Hernendez A.F., Barbier F., Ayouni L., and Gil F. (2013): Determination of Toxic Elements (Mercury, Lead, Cadmium, Tin and Arsenic) in Fish and Shellfish Samples. Risk Assessment for the Consumers. Environment International. 59:63-72

Sa'eed M.D. and Mahmoud A.M. (2014): Determination of some Phicochemical Parameters and some Heavy Metals in Boreholes from Fagge L.G.A. of Kano Metropolis, Kano State-Nigeria. World Journal of Analytical Chemistry. 2:2:42-46

Usman A.M. and Lar U.A. (2013): Overview of Arsenic distribution in some parts of Biu Volcanic Province, North-Eastern Nigeria. Earth Science. 2:6:145-148

World Health Organization (WHO), (2011): Guidelines for Drinking water quality, $4^{\text {th }}$ Edition.

www.h2odistributors.com retrieved 6:30 p.m., $25^{\text {th }}$ February, 2016. 